\title{
東京における長期地下水位変動解析 ANALYSIS OF LONG-TERM GROUNDWATER LEVEL FLUCTUATION IN TOKYO
}

\author{
石原成幸 1 - 河村明 2 - 天口英雄 3 - 高崎忠勝 4 - 川合将文 5 \\ Shigeyuki ISHIHARA, Akira KAWAMURA, Hideo AMAGUCHI, \\ Tadakatsu TAKASAKI, and Masafumi KAWAI
}

\author{
1正会員＼cjkstart修(学) 東京都土木技術支援・人材育成センター（干136-0075 東京都江東区新砂1-9-15） \\ 2正会員 工博 首都大学東京大学院 都市環境科学研究科（干192-0397 東京都八王子市南大沢1-1） \\ 3 正会員 博(工) 首都大学東京大学院 都市環境科学研究科（干192-0397 東京都八王子市南大沢1-1） \\ 4正会員＼cjkstart博(工) 東京都建設局＼cjkstart河川部（干163-8001 東京都新宿区西新宿2-8-1） \\ 5 東京都土木技術支援・人材育成センター（干136-0075 東京都江東区新砂1-9-15）
}

In this study, the fluctuation patterns of the long-term groundwater levels at 87 confined and 13 unconfined water observation wells in 42 sites in Tokyo Metropolis were investigated using SelfOrganizing Maps (SOM). The SOM application classified the yearly groundwater level fluctuation patterns into eight clusters showing clearly distinguishable patterns which were then divided into 3 large groups. Consequently, the results show that the fluctuation patterns of natural groundwater levels were classified into Group-1. Most of the wells in the Tama region which showed regular fluctuation patterns caused by pumping were classified into Group-3. However, the majority of the wells were moved to Group-2 due to the pumping of drinking water being suspended or decreased. These results show that the SOM analysis was successful in extracting the unique long-term fluctuations of groundwater levels.

Key Words : groundwater level, long-term fluctuation, observation well, Tokyo, SOM (Self-Organizing Map)

\section{1. はじめに}

1940(昭和15)年4月，東京都土木技術支援・人材育成 センター（以下「センター」と記す）の前身である東京 都土木技術研究所では, 防災並びに防潮対策を目的とし て, 都内における地盤沈下調査を東京帝国大学地震研究 所から引き継いで実施することとなった. その後, セン ターでは今日に至るまで当該調査の一貫として, 東京に おける地盤沈下対策の基礎資料となる 1 級水準測量と地 下水位観測を継続的に行っている.

これらの成果を用いた東京における地下水の調査・研 究としては, 古くから様々な研究が行われているが，大 別すると水循環や地下水涵養の視点からの研究1), 地下 水の水質 ${ }^{2}$ や地形地質との関係 ${ }^{3}$ についての研究, 地盤 沈下等との関連に係る調査・研究4)などが多い.ここで, 地下水位そのものの変動に関する調査としては，降水量 との相関についての研究5)が多数を占める. またセン ターでは地下水位観測成果を公表しているが，その変動 特性の分析までは行っていない. 著者らは既に, 東北地
方太平洋沖地震（以下「東日本大地震」と記す）に伴う 2011年3月1箇月間の1時間単位の観測データなどを用い, 東京での特徵的な短期地下水位変動パターンの解析に成 功した6) 8). しかし，東京における長期的な地下水位の 変動パターン解析について管見では承知していない.

現在，東京都内の地下水位は，法令に基づく揚水規制 等の効果により上昇または横ばい傾向にあり，地盤沈下 が沈静化していることから地下構造物の浮力・漏水対策 や水資源として，地下水の利活用が注目を集めている. 特に，多摩地域を中心とする都内全域では，上水道や工 場等の水源として日量約 50 万 $\mathrm{m}^{3}$ 弱の地下水が揚水され るなど，重要な水資源となっている99.ささら近年では， 地震時等の災害対策としての防災井戸や病院の非常用水 源としての活用など，地下水利用に対する社会的要望は 強くなっている10),11). その許可を受けた多くの防災井戸 では, ストレーナの目詰まり防止等を理由に, 日常的に 地下水利用がなされている.このため, 防災名目による 地下水利用を広く認めた場合, 恒常的かつ多量の地下水 揚水に伴う地下水位の低下とそれに起因する地盤沈下の 
再燃等も懸念されている9.

よって，地盤沈下を生じさせずに地下水活用を図るに は，長期的な地下水位の変動を正確に捉えることが非常 に重要となってくる. 加えて, その特徵的な地下水位変 動と要因の相関関係を把握することは, 水循環体系に与 える影響や長期的な水位変動傾向を予測するうえからも 有効であり, 将来にわたり貴重な知見になると考える.

そこで本論文では，センターの地下水位観測システ ムによる2003 (平成13)年から2012 (平成24)年の10箇年に おける各月の地下水位データを用い，42観測局（地点） 100井における地下水位の年間変動パターンの長期的な 変動を抽出し，その変動傾向について評価した．具体的 には，観測システムにおいて得られた久測等の少ない観 測井の月平均地下水位 10 箇年データについて, 複雑な データの相互関連性を二次元平面に視覚化することで データ特性の発見等に優れた自己組織化マップ（SelfOrganizing Map，以下「SOM」と記す）を用い，客観的 にパターン分類のうえクラスター化し, 地下水位の年間 変動パターンの長期的な変動特性や空間分布特性を明ら かにした。 また，その解析結果を関連資料により検討し， 地下水位とその変動要因について言及した.

\section{2. 使用したデータ及びSOMの適用}

\section{（1）入力に用いたデータ}

図-1には，東京都内（島嶼・山地を除く）に設置され ているセンターの地下水位観測局の局名と局番号等を示 した．また表-1には，今回解析に使用した2003年から 2012年における各観測井の水位データのうち，9観測局 20 観測井の詳細を例示した。 なお，入力データは長期欠 測等を除 $<42$ 観測局 100 井（被圧 : 87, 不圧 : 13）にお いて, 以下の方法により求めた10箇年分の月単位の地下 水位である.

(1) 2003〜2012年の10箇年に観測された1時間単位の観測 データより， $i$ 観測井の $n$ 年目 $m$ 月における地下水位の月 平均值 $x_{i, n, m}(i=1 \sim 100 ; n=1 \sim 10 ; m=1 \sim 12)$ を求めた.

(2) 上記の 120 箇月分の月平均地下水位值 $\left(x_{i, n, m}\right)$ から, 各年における年平均の地下水位值 $\left(\bar{x}_{i, n}\right)$ を求めた.

(3) SOMへの入力データとしては, 各観測井における各

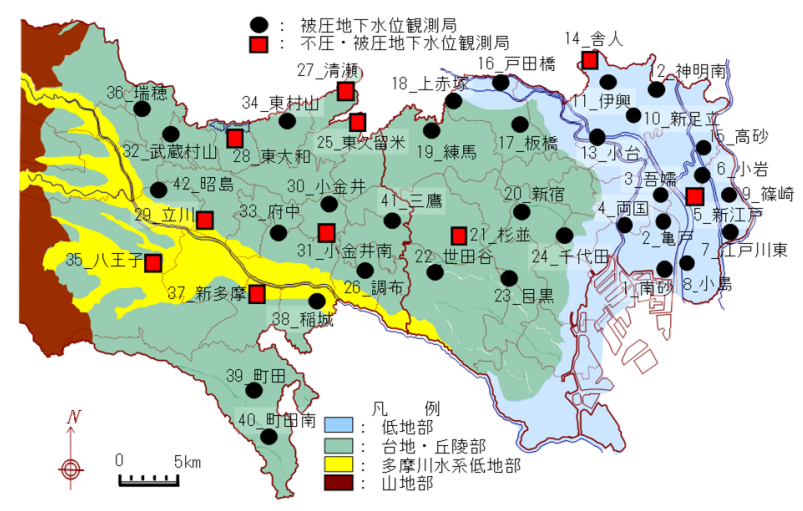

図-1 地下水位観測局の配置状況
表-1 観測井及び使用データ（抜粋）

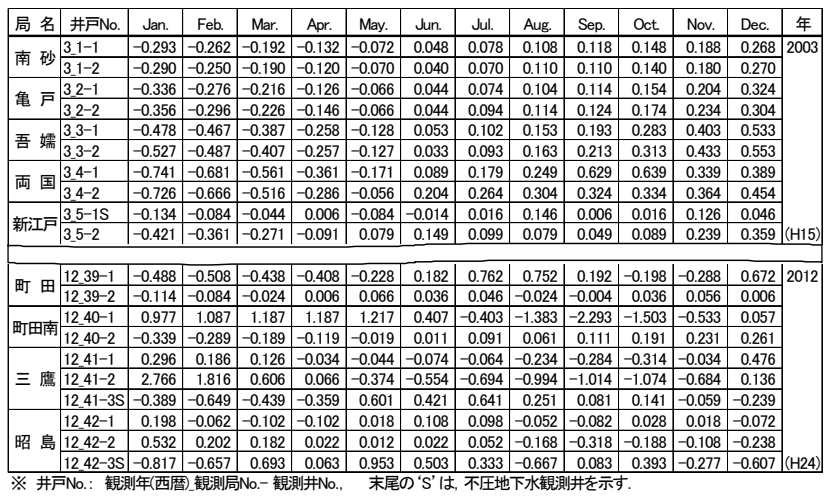

年1 12月で構成する各月平均水位值から年平均水位值 を差し引いた值 $\tilde{x}_{i, n, m}\left(=x_{i, n, m}-\bar{x}_{i, n}\right) て ゙ ， 100$ 井・10箇年の 合計 1,000 データである.

\section{（2）SOMの適用}

SOMは, 入力データの関連性を類似度としてマップ 上に描画できるニューラルネットワーク手法の一種であ る. この機能により，一般的に捉えにくい多次元のデー タを二次元マップ上に分類し，客観的かつ可視的に表現 することができる.このため，これまでに水文・気象分

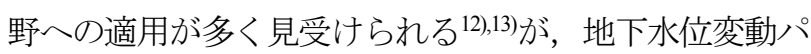
ターン特性への適用に関しては, 著者らの成果7,8) 以外 はほとんど見受けられない。

図-2には，今回適用したSOMのノードマップを示す． $\mathrm{SOM}$ の入力ベクトル $X(j)(j=1 \sim 1,000)$ は, $\left[\tilde{x}_{i, n, 1}, \cdots, \tilde{x}_{i, n, 12}\right]$ とする12次元（各年1 12月）で構成 され，そのデータ数は $1,000(=100$ 井 $\times 10$ 年 $)$ である.

$\mathrm{SOM}$ のノード数 $M$ は, 入力データ数 $n$ に基づく経験式 $M=5 \sqrt{n}$ から近似的に求められる. 本研究において $n=1,000$ からノード数 $M$ は 158 であり, これにデータの共 分散行列における固有值ベクトルの第 $1 \cdot 2$ 成分の比率に 基づき，ノードマップを縦14×横11の154ノードと決定 した ${ }^{14)}$.

$\mathrm{SOM}$ ノードマップの各ノードには, 入力ベクトル $X(j)$ と同じ次元を持つ参照ベクトル $R(k)(k:$ ノード番号) が 配置されており, 入力ベクトルの特徴 (パターン) はこ の参照ベクトル $R(k)$ によって表現される. 入力ベクトル は全ノードに割り当てられた参照ベクトルと比較され， 両者のユークリッド距離が最小となる勝者ノードが探索 される. 各ノードの参照ベクトルは勝者ノードとの距離 で表される近傍関数に従い修正される. 従って, 勝者 ノードに近い参照ベクトルほど修正量が大きくなるよう に競合学習が行われ，その修正の程度は学習回数ととも に小さくなる. 最終的に, 複雑な入力ベクトルの特徵 (パターン) はノードマップ上の参照ベクトルで表現さ れ，ノードマップ上で距離が互いに近いノードほど類似 した特徵を持ち, 遠いノードほど互いに異なる性質を持 つよう参照ベクトルの值が組織化される ${ }^{12,13) .}$ 


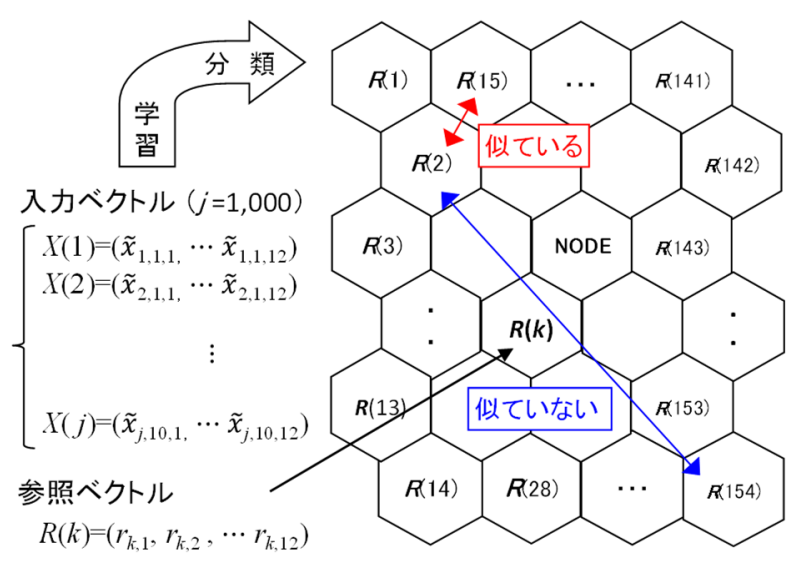

図-2 SOMノードマップ $(14 \times 11$ ノドの配列)

次に，SOMで得られた参照ベクトル（ノード）のクラ スター化を行った. 本研究ではクラスターの最適数を K-means法に基づく最小DBI（Davies-Bouldin Index）值 により決定し，クラスター分類はウォード法を用いた ${ }^{15)}$.

\section{SOMによる地下水位変動パターンの結果}

図-3ノードマップは，100井・10箇年の入力ベクトル $\tilde{x}_{i, n, m}$ にSOMを適用して得られた参照ベクトル $R(k)$ を 0 $1 の$ 值に規準化し, 全体的な地下水の季節変動を捉える ために月別に示したものである.

図-3から，1～3月の水位変動傾向が類似しており，4 〜6月にかけて暫時変化する. その後，7～9月に類似傾 向を示したのち，10月の変化を経て11・12月の分布傾向 が類似していることが読み取れる．また，各月の分布傾 向としては1〜3月の特に右上端ノードの水位が顕著に高 く, 右下端ノードの水位が特に低い傾向を示している. 4〜6月にかけては，上側の特に右端のノードの水位が大 きく低下し，左端のノード全体が高い水位傾向を示寸. その後，7～9月には下半分のノードの水位が著しく上昇
するのに対し，上半分のノードの水位が徐々に低下して いる．10月には中央部から下半分のノードの水位も低下 し始め，11・12月には右下端ノードの水位が高くなる変 移を示している．12月には，右下端ノードの水位だけが 高いという特異性を示している．以上のとおり，変動パ ターンとしては年前半で上側ノードの水位が高く，逆に 後半において下側ノードの水位が上昇し，年末には限ら れた一部のノードを除き全体的に低下するという特徴を 有する.

図-4には，前述の手法により最小DBI值が8となるこ とから，154のノードを8つのクラスターに分類した結果 とともに，各クラスターに分類されたノード番号を樹形 図として示した.さらに図-5では図-4に示した各ノード に配置された観測井の詳細が判るように，SOMノード マップ上に各クラスターとノード並びに各ノードに配置 された観測井の状況を示した。眓中の表示は「観測年_ 観測局No._井戸No.」である.また表-2には，クラス ター毎に分類されたデータ数の内訳を示した.

\section{10箇年における地下水位の変動パターン特性}

\section{（1）各クラスターの地下水位の変動パターン特性}

図-6には，8クラスター毎の特徵を明らかにするため, 各クラスターに属する参照ベクトル $R(k)$ の第1四分位, 中央值，第3四分位を $-3 \sim+3$ の範囲でプロットした. 図-6に基づき，特徵のあるクラスターを以下に例示する. 図 (a)のクラスター 1 は 1 6月に平均水位より若干高い傾 向から，7～12月にかけて徐々に水位が低下寸る傾向に ある．また図 (c)・(e)のクラスター3・5についても，水 位の変動パターンが類似している点が共通している. 次 に，図(f)のクラスター6は，8クラスター中で最も水位 変動が少なく, 年間を通じて平均水位を維持する傾向に ある. 図(b)・(d)のクラスター2・4についても，水位上 昇幅は若干大きいが類似した変動パターンを有している.
4 月
5 月
6 月

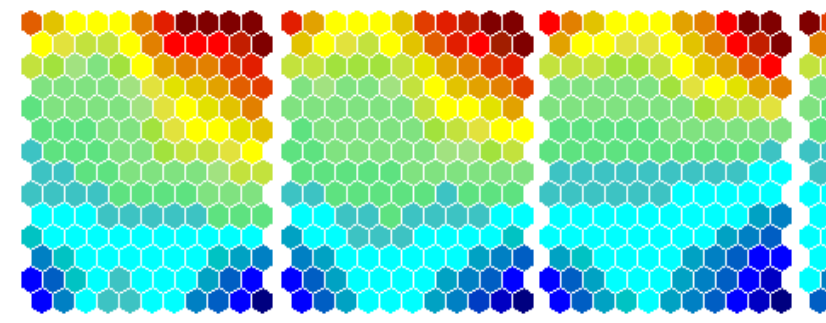

7 月
8 月

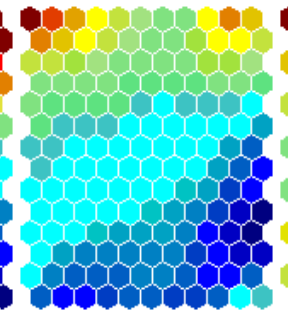

10 月

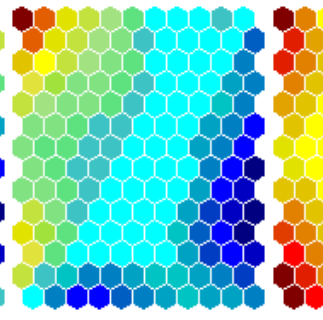

11 月

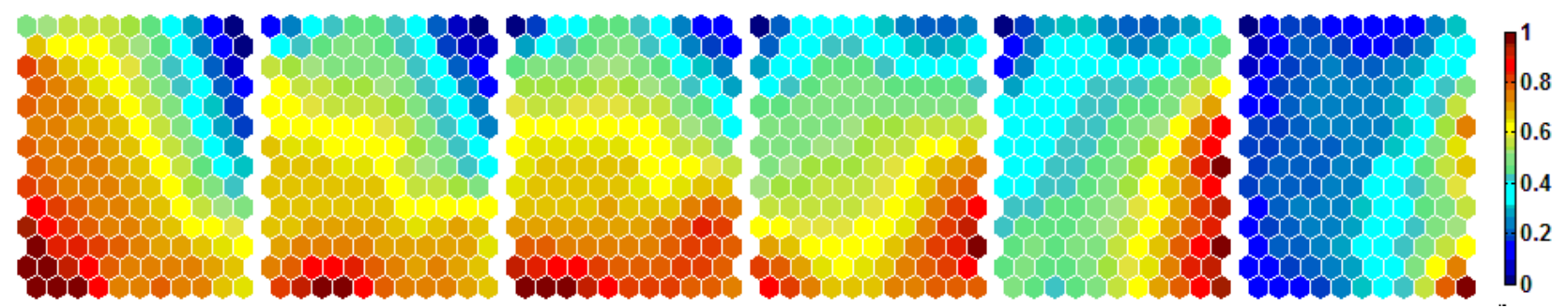

図-3 2003〜2012年における100井の月別の水位変動分布パターン（規準化） 


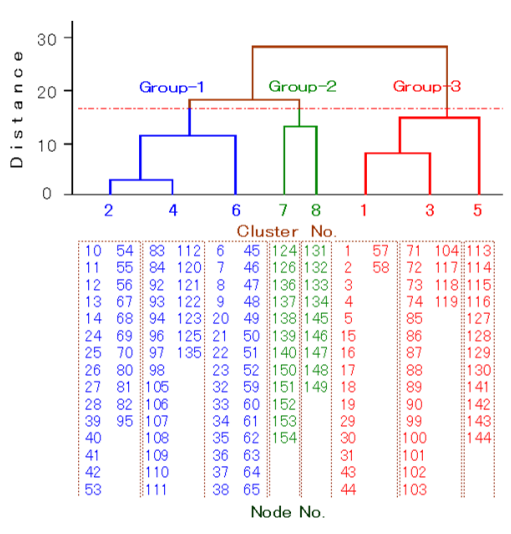

図-4 クラスター階層とノード区分

表-2 クラスター別のデータ数

\begin{tabular}{|c|c|c|c|}
\hline クラスターNo. & データ数 & 小計 & グループNo \\
\hline Cluster -1 & 106 & \multirow{3}{*}{258} & \multirow{3}{*}{ Group-3 } \\
\hline Cluster -3 & 93 & & \\
\hline Cluster -5 & 59 & & \\
\hline Cluster -2 & 162 & \multirow{3}{*}{624} & \multirow{3}{*}{ Group-1 } \\
\hline Cluster -4 & 116 & & \\
\hline Cluster -6 & 346 & & \\
\hline Cluster -7 & 81 & \multirow{2}{*}{118} & \multirow{2}{*}{ Group-2 } \\
\hline Cluster -8 & 37 & & \\
\hline 合＼cjkstart計 & \multicolumn{2}{|c|}{1,000} & \\
\hline
\end{tabular}

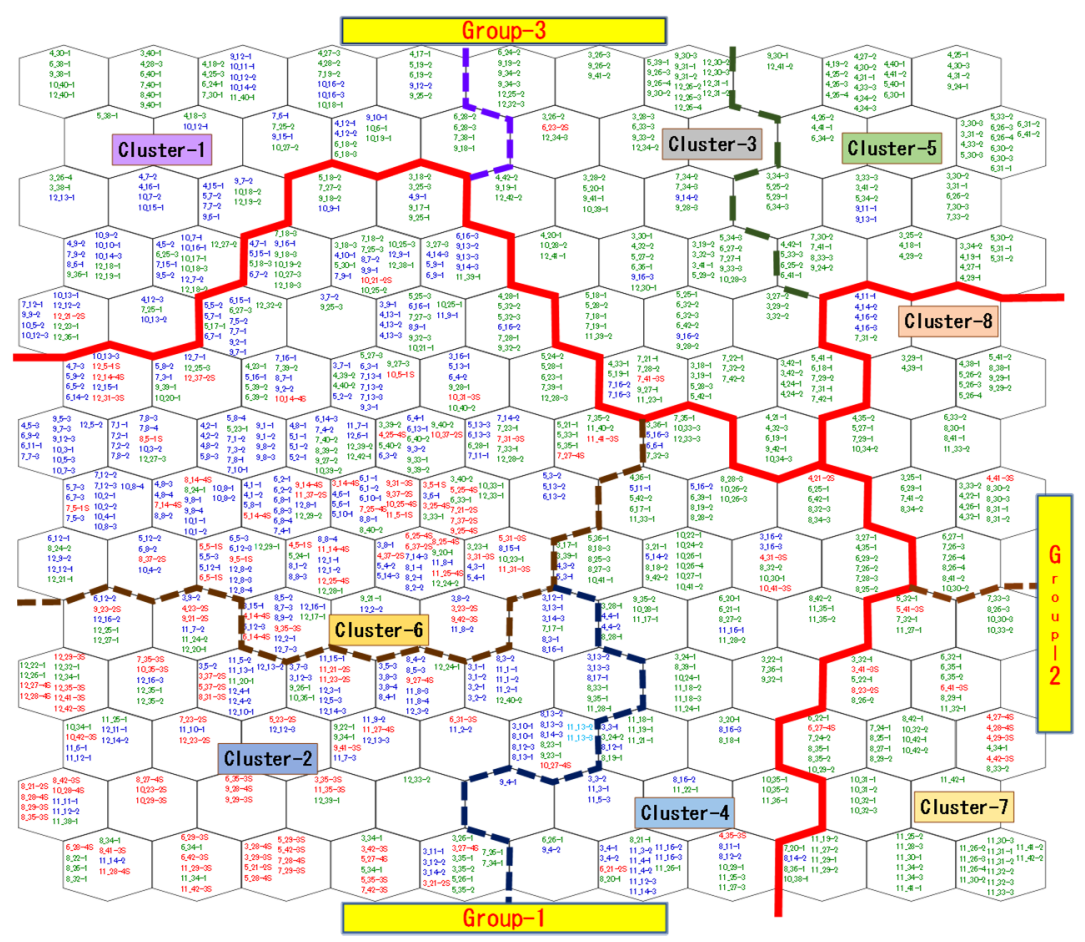

一凡 例- 青: 被圧地下水一低地部, 緑: 被圧地下水-台地部, 赤: 不圧地下水一低地部 - 台地部 図-5 クラスター・ノード別の観測井の分布パターン
(a) Cluster-1
(b) Cluster-2
(c) Cluster-3
(d) Cluster-4
(e) Cluster-5
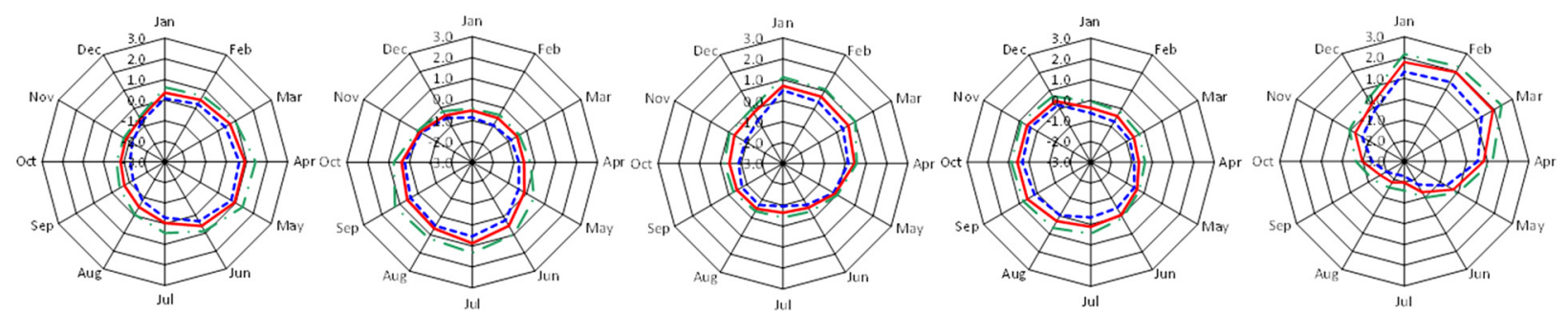

(f) Cluster-6

(g) Cluster-7

(h) Cluster-8
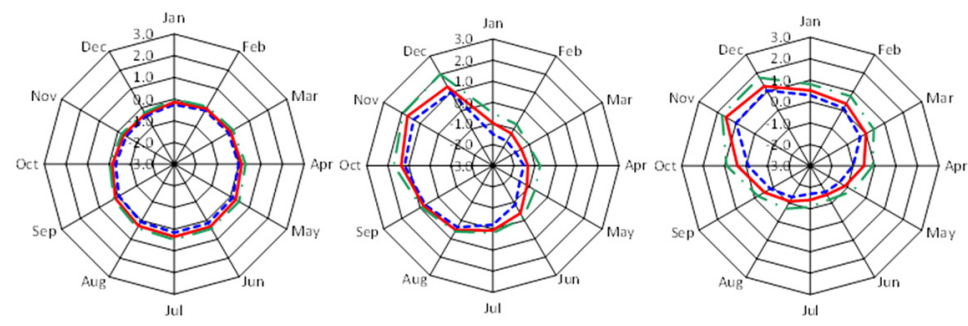

- 凡 例 -

- - - 第1四分位

一中央値

- - 第3四分位

範囲: $-3 \sim+3$

図-6 各クラスターにおける月別の水位変動の分布特性

図 (g)のクラスター7は，年前半に水位が平均より低下し， 年後半にかけて水位が大きく上昇したのち, 年末に若干 低下する傾向にある. 図(h)のクラスター8についても比 較的似た水位変動傾向にある.

上記の水位変動傾向に基づき，当該8クラスターを特 徵別に3つのグループに区分することとし， クラスター 2·4·6をグループ1, 同様にクラスター7·8をグループ2, クラスター $1 \cdot 3 \cdot 5$ をグループ3と定めた。 なお，図-4 5 及び表-2にグループ毎の分類結果を併記する.
（2）10箇年における水位変動のパターン分布とその要因

図-7には，大別した各グループに属する主な観測井 の月平均の地下水位, 東京管区気象台における月当たり 降水量及び都内の水道水源亡工場等の月当たり揚水量の 変動状況を示す．同図と図-5より，以下にグループ毎の 水位変動の特徵を記す.グループ1に都内全域の多くの 観測井が分類され, 水位変動が比較的少ないこと, グ ループ2に2010・2011年の多摩部を中心とする観測井が分 類され, 最も大きな水位変動を示すこと, グループ3が 主に2003〜2010年の台地部全域の観測井が分類され，グ 


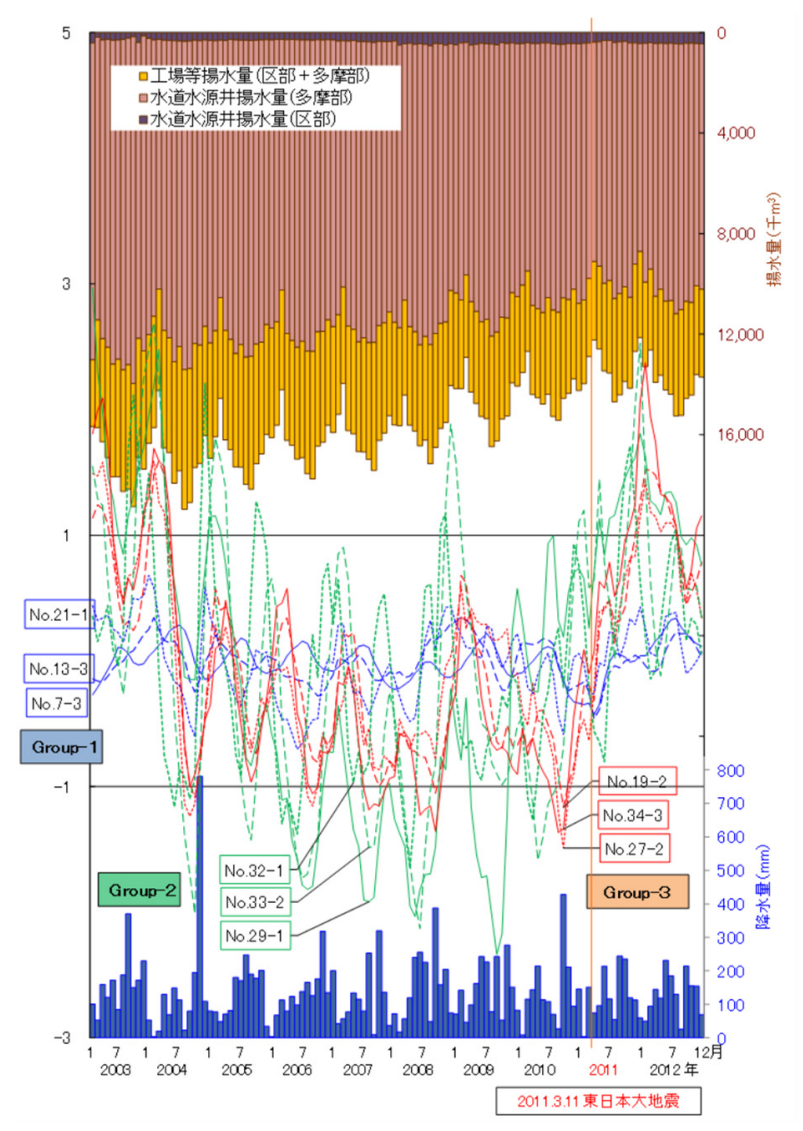

図-7 10箇年の月別の地下水位，降水量と揚水量の変動

ループ1・2の中間的な水位変動を示すという特徵が確認 できる.

図-8には，10箇年間における主な地下水位変動パ ターンの時空間特性の変化を示した. 同図 (a)〜 (d) には, 2003 2009年の標準的な変動傾向かつ調査初年である 2003年並びに顕著な変化のあった2010～2012年の各観測 局の被圧観測井（深度70～417m）について，地点毎に 変動グループの分布状況を示した．また，水道水源井の 揚水量が特に多い地域等を着色して示した ${ }^{10}$. ここで, 井戸深度を $70 \mathrm{~m}$ で区分したのは, $70 \mathrm{~m}$ 未満の観測井が 15 井と少なく地域分布に偏りがあること，東京における主 な帯水層の分布や地下水位に及ぼす体積歪変化の感度が 鮮明となる深度等を考慮したことによる4),17).

図 (a)には，2003年における地下水位変動パターンの 分布傾向を示した. 主な特徵としては区部低地部と台地 部にグループ 1 ，水道水源の日揚水量が 1 万 $\mathrm{m}^{3}$ を超える 多摩部を中心にグループ3, その他の多摩部にグループ1 が分布している. 図(b) は2010年の分布傾向を示し, 図 (a)において変動パターンがグループ1であった地点のう ち，千葉・埼玉県境付近のものがグループ3に変化した. また，この年は日揚水量 1 万 $\mathrm{m}^{3}$ 超の地域から練馬区及び 稲城市が外れ、東大和市が加わった．これらに伴い，当 該地域の日揚水量が約 47 万 $\mathrm{m}^{3}$ から 40 万 $\mathrm{m}^{3}$ 未満に大きく 減少し10, 多摩川左岸を中心に揚水量の多い地域の変動 パターンがグループ3からグループ2に変化している. 図
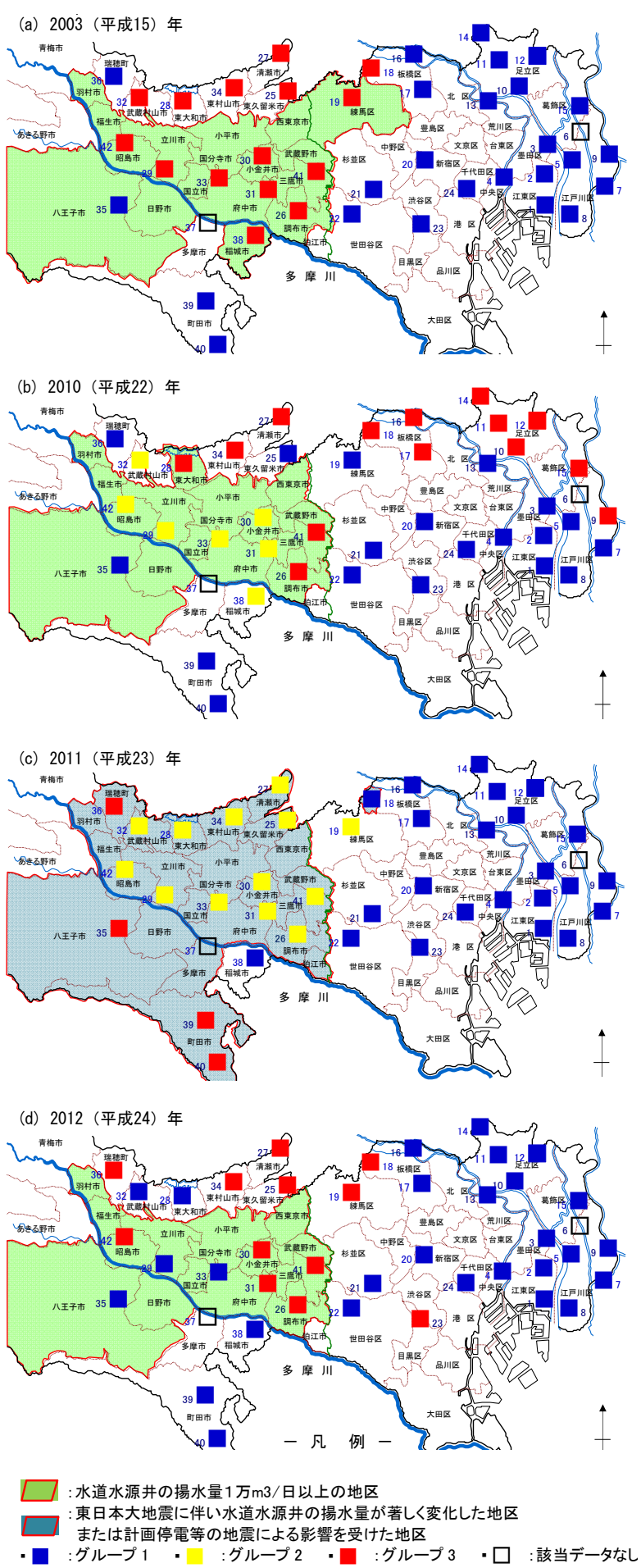

図-8 観測局別の地下水位変動グループの空間分布

(c) は東日本大地震が発生した2011年の変動パターンで あり，ほぼ区部全域がグループ1となった。また多摩部 では地震直後の計画停電や施設修繥等の影響により, 水 道水源などの揚水が一時停止し，前年までに比べて日揚 水量が約 3 万 $\mathrm{m}^{3}$ 減少した ${ }^{16}$. このため，平常時に日揚水 量の多い地域がグループ2となり，多摩川右岸などでグ ループ3に変化している. 図(d) は地震後の2012年の水位 変動パターンの傾向である. 区部では一部を除き変化は 見られないが，多摩部では揚水の再開に伴って日揚水量 


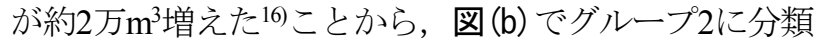
された地点を中心にグループ1に変化し，区市境と東京 都・埼玉県境付近の地点がグループ3となった.

また，同図及び図-7からは従前に比べて2010年以降 の揚水量が大きく減少しており, 特に東日本大地震の あった2011年の多摩部が顕著であること，翌年には再び 増加傾向にあることが読み取れる. 図-8(d)のグループ2 からグループ1に変化した地点付近では揚水量がほぼ 2010年レベルであるのに対し，グループ3となった地点 及び隣接地域では日揚水量約 1 万 $\mathrm{m}^{3}$ の増加16に伴って変 動したこと, 同様に図-8 (b) で都県境付近などの変動パ ターンがグループ1からグループ3に変化したのは，主に 隣接県における揚水量の変動に起因していることを確認 している4),7.

以上のことから，区部での揚水規制に伴い自然状態 に近い，または揚水量の変動の少ない地下水位の年間変 動パターンがグループ1に相当し，平年の揚水量の多い 地域において揚水量が大きく変動した場合の年間変動パ ターンをグループ2，また多量の揚水などの人為的な影 響を受けている場合の年間変動パターンがグループ3に 分類されたことが考察できる．なお，紙面の関係で詳細 を記すことができなかった不圧地下水観測井については， 水道水源井による揚水の影響を直接受けておらず，降水 量との相関が高いことから 4 ),7)，地域に関わらずほぼグ ループ1の変動パターンを示すことを確認している.

\section{5. むすび}

本論文では，東京都内の地下水位観測 42 局 100 観測井 における10箇年の月単位の水位值を用い, SOM解析に より長期的な地下水位の年間変動パターンの特性分類と その要因の考察を試みたＳSOM解析の結果，2003〜 2009年の地下水位の変動パターン特性と比較して, 2010 ～2012年3箇年の変動パターン特性が大きく変化してお り，かつ空間分布に明膫な傾向のあることを明らかにし た.さらに，都内における地下水位の年間変動パターン の長期的な変化の特徵は, 人為的影響が少ない場合の地 下水位の変動パターンをグループ1，水道水源による多 量の揚水等の人為的影響を受けた場合がグループ3，人 為的影響のある地域で揚水量が大きく変動した場合にグ ループ2として分類できた．これにより，地下水分野に おける 12 次元 1,000 データという多次元のデータ解析に おいて, 特徵的な変動パターンを二次元化して抽出可能 なことが確認できた.

これは今後の地下水管理において，地盤沈下を生じ させない範囲で地下水活用を図る際に必要となる揚水 量・水位関係の定量的な評価, 地下水位の変動パターン 予測などに資する有益な知見になると考える.
1) 国分邦紀, 土屋十图 : 東京の地下水と水循環について, 水 文・水資源学会誌，Vol.16，No.3,pp.289-300，2003.

2）宮越昭暢，林武司，丸井敦尚，佐倉保夫，川島眞一，川合 将文: 地下温度からみた東京低地における地下水環境変化 の評価，応用地質，Vol.47, No.5, pp.269-279, 2006.

3) 細野義純: 東京付近における不圧地下水の環境地理学的研 究, 奈良大学紀要, 第31号, pp.147-165, 2002.

4) 東京都環境局 : 東京都の地盤沈下と地下水の再検証につい て，平成22年度地下水対策検討委員会のまとめ, 2011.

5) 駒村正治, 増野途斗, 成岡市: 地下水位変動と地下水涵養 機構，水文・水資源学会誌，Vol.16, No.6, pp.631-639, 2003.

6）石原成幸，河村明，天口英雄，高崎忠勝，川合将文 : 東北 地方太平洋沖地震に伴う東京における不圧・被圧地下水位 の変動特性，土木学会論文集B1（水工学），Vol.68, No.4, pp.I_595-I_600, 2012.

7) 石原成幸, 河村明, 天口英雄, 高崎忠勝, 川合将文 : 自己 組織化マップを用いた東北地方太平洋沖地震に伴う東京に おける地下水位の変動特性評価, 土木学会論文集B1（水工 学)，Vol.69, No.4, pp.I_541-I_546, 2013.

8）石原成幸，河村明，天口英雄，高崎忠勝，高橋泰之，川合 将文 : 自己組織化マップを用いた東北地方太平洋沖地震発 生前後での東京の年間地下水位変動特性，土木学会論文集 B1（水工学）,Vol.70, No.4, pp.I_1129-I_1134, 2014.

9) 中嶋博，金子紘士，土田稔 : 東京都における地盤沈下対策 と地下水保全対策, 地下水学会誌, Vol.52, No.1, pp.35-47, 2010.

10) 植村哲士，宇都正哲，中川隆之，向井肇：総合的な水資源 管理の必要性と鍵となる未使用淡水資源の活用，知的資産 創造，2010年9月号，pp.6-19, 2010.

11) 守田優 : 地下水は語る一見えない資源の危機, 岩波新書, pp.160-193, 2012.

12) 井芹慶彦，水本真輝，神野健二，西山浩司：自己組織化 マップを用いた日本全国月降水量分布の変動特性解析，水 文·水資源学会誌, Vol.22, No.6, pp.466-478, 2009.

13) 西山浩司, 遠藤伸一, 神野健二, 河村明 : 自己組織化マッ プを利用した梅雨期特有の気象場の分類, 土木学会水工学 論文集, Vol.49,pp.241-246, 2005.

14) Hilario, L. G. and Ivan, M. G. : Self-organizing map and clustering for wastewater treatment monitoring, Engineering Applications of Artificial Intelligence, Vol.17, pp.215-225, 2004.

15) Scott, K. E. and Oyana, T. J. : An improved algorithm for segregating large geospatial data, $9^{\text {th }}$ AGILE Conference on Geographic Information Science, pp.177-185, 2006.

16) 東京都環境局 : 平成15 平成24年 都内の地下水揚水の実 態（地下水揚水量調查報告書）平成17～26年3月, 2014.

17) 地質調查所:1995年兵庫県南部地震直後の関西地区と徳島県 に㧍ける地下水位変化, 地震予知連絡会報, 58, pp.500-504, 1997. 